УДК 336

https://doi.org/10.35546/kntu2078-4481.2021.4.25

Т.М. ПОВОД

Херсонський державний аграрно-економічний університет

ORCID: 0000-0001-8191-5488

\title{
СВІТОВИЙ ДОСВІД ВИЗНАЧЕННЯ ДЕТЕРМІНАНТ ФІНАНСОВОЇ ГРАМОТНОСТI
}

Розглянуто сучасний стан фінансової грамотності населення в Україні, визначено причини незадовільної ситуації у цій сфері. Зазначено, щэо фінансова грамотність населення $\epsilon$ ключовим моментом для подальшого розвитку успішного суспільства, тільки фінансово освідченні громадяни можуть раціонально формувати і використовувати власний бюджет, приймати правильно виважені фінансово-економічні рішення та орієнтуватися в сучасних фінансових інструментах та послугах щуо масово пропонуються. А суспільство, яке складається з людей, які розумно і правильно використовують свої фінансові ресурси, розуміють деталі отримання та користування кредитом, розглядають можливості відкриття та розвитку власного бізнесу, иляхи та умови реалізації своїх бізнес-ідей, зміцнюють своє економічне та фінансове становище є фінансово грамотним суспільством. Узагальнено детермінанти, досвід та сучасні підходи США, Великобританії та інших країн світу, щзодо можливостей трансформації навчання населення. Акцентовано увагу на комплексності вирімення питань щцодо приведення у відповідність можливостей розвитку життєвих компетентностей населення краӥни з урахуванням перспективи. Вивчено сучасний досвід фінансового розвитку, запропоновано основні напрями підвищення фінансової грамотності громадян з урахуванням передового світового досвіду. Доказано, щуо незважаючи на велику кількість досліджень фінансової грамотності, проблема досягнення ї̈ високого рівня залишається актуальною, оскільки забезпечення добробуту громадян тісно пов'язане з реалізацією державних інтересів иляхом залучення ресурсів на ринок фінансових послуг, а це є важливим фактором економічного зростання національної економіки.

Ключові слова: фінансова грамотність, детермінанти, фінанси, фінансова освіченість, фінансові продукти і послуги, фінансовий розвиток.

Т.М. ПОВОД

Херсонский государственный аграрно-экономический университет ORCID: 0000-0001-8191-5488

\section{ЗАРУБЕЖНЫЙ ОПЫТ ОПРЕДЕЛЕНИЯ ДЕТЕРМИНАНТ ФИНАНСОВОЙ ГРАМОТНОСТИ}

Рассмотрено современное состояние финансовой грамотности населения в Украине, определены причины неудовлетворительной ситуации в этой сфере. Отмечено, что финансовая грамотность населения является ключевым моментом для дальнейшего развития успешного общества, что только финансово осведомленные граждане могут раџионально формировать и использовать собственный бюджет, принимать правильно взвешенные финансово-экономические решения и ориентироваться в современных финансовых инструментах и массово предлагаемых услугах. $A$ общество, состоящее из людей, которые разумно и правильно используют свои финансовые ресурсы, понимают детали получения и пользования кредитом, рассматривают возможности открытия и развития собственного бизнеса, условия реализаџии своих бизнес-идей, укрепляют свое экономическое и финансовое положение является финансово грамотным обществом. Обобщены детерминанты, опыт и современные подходы США, Великобритании и других стран мира относительно возможностей трансформации обучения населения. Акцентировано внимание на комплексности решения вопросов приведения в соответствие возможностей развития жизненных компетентностей населения страны с учетом дальнейших перспектив. Изучен современный опыт финансового развития, предложены основные направления повымения финансовой грамотности граждан на основе мирового опыта. Доказано, что, несмотря на большое количество исследований финансовой грамотности населения, проблема достижения ее высокого уровня остается актуальной, поскольку обеспечение благосостояния граждан тесно связано с реализачией государственных интересов путем привлечения ресурсов на рынок финансовых услуг, а это является важным фактором экономического роста начиональной экономики.

Ключевые слова: финансовая грамотность, детерминанты, финансы, финансовая образованность, финансовые продукты и услуги, финансовое развитие. 
T.M. POVOD

Kherson State Agrarian and Economic University ORCID: 0000-0001-8191-5488

\section{FOREIGN EXPERIENCE OF DETERMINANT DEFINITION FINANCIAL LITERACY}

The current state of financial literacy of the population in Ukraine is considered, the reasons of unsatisfactory situation in this sphere are defined. It is noted that financial literacy of the population is a key point for further development of a successful society, only financially savvy citizens can rationally form and use their own budget, make sound financial and economic decisions and navigate in modern financial instruments and services offered en masse. And a society consisting of people who use their financial resources wisely and correctly, understand the details of obtaining and using credit, consider opportunities to open and develop their own business, ways and conditions of implementing their business ideas, strengthen their economic and financial position is financially literate society. The determinants, experience and current approaches of the USA, Great Britain and other countries of the world on the possibilities of transforming the education of the population are generalized. Emphasis is placed on the complexity of resolving issues related to bringing the opportunities for the development of life competencies of the population of the country in line with the prospects. The modern experience of financial development is studied, the basic directions of increase of financial literacy of citizens taking into account the advanced world experience are offered. It has been proven that despite the large number of studies of financial literacy, the problem of achieving its high level remains relevant, as ensuring the wellbeing of citizens is closely linked to the interests of the state by attracting resources to the financial services market.

Key words: financial literacy, determinants, finance, financial education, financial products and services, financial development.

\section{Постановка проблеми}

Стрімке розширення фінансових відносин у всі сфери людського життя актуалізує проблему кращої інформованості людей про свої фінанси, загострилися проблеми непосильного особистого боргового навантаження, відсутності ефективних заощаджень, нездатності громадян вживати ефективних заходів, спрямованих на захист власного добробуту. Тому у сучасних умовах розвитку України реформування економіки, освіти, фінансової культури є ключовим моментом прогресу 3 формування фінансової освіти населення. Саме фінансова грамотність займає одне $з$ важливих місць у розвитку успішного суспільства, забезпечуючи можливість кожного громадянина раціонально формувати свій власний бюджет, орієнтуватися у виборі фінансових інструментів та послуг, приймати виважені фінансові рішення. Розвинені країни світу постійно надають увагу питанням і проблемам підвищення фінансової освіти населення, зокрема США, Великобританія, Канада, Нідерланди, Австралія, Нова Зеландія, спрямовують багато зусиль на підвищення фінансової грамотності населення. Найкращі практики об'єднуються під егідою потужних міжнародних організацій: Світового Банку, Організації економічного співробітництва та розвитку (ОЕСР), Агентства США з міжнародного розвитку (USAID) та ін.

\section{Аналіз останніх досліджень і публікацій}

Наукові дослідження у сфері фінансової грамотності здійснювалися зарубіжними вченими К. Кутером, А. Лусарді, О. Мітчеллом, а також такими провідними вітчизняними науковцями такими, як: Л. Гончар, А. Мартиненко, Т. Кізима, Б. Приходько, Т. Смовженко, С. Юрій, І. Ломачинська, І. Клапків, О. Дудчик, I. Матвійчук та ін. У більшості робіт вітчизняних науковців проблема підвищення фінансової грамотності населення України розглядається крізь призму використання світового досвіду. Не зважаючи на широке коло науковців, що займаються питаннями фінансової грамотності, проблеми продовжують накопичуватися та набувають актуальності в сучасних умовах економічного і фінансового розвитку.

\section{Формування мети дослідження}

Метою дослідження є оцінка рівня фінансової освіти різних верств населення України та визначення умов підвищення фінансової грамотності громадян 3 урахуванням передового світового досвіду.

\section{Викладення основного матеріалу дослідження}

Світова практика свідчить, що сьогодні в кожній родини середнього добробуту повинен бути свій сімейний лікар, юрист та фінансовий консультант. Який повинен супроводжувати людину або иї родину все життя і допомагати приймати правильні рішення: 3 кредитування, страхування, накопичення коштів, придбання цінних паперів, відкриття рахунків у банку та інших операцій [1].

Тому сьогодні проблема фінансової грамотності $є$ актуальною практично для усіх країн світу. Фінансова грамотність визначає успішність взаємодії фізичних осіб (домогосподарств, суб'єктів 
підприємницької діяльності) 3 діючими фінансовими інституціями. В широкому розумінні, саме фінансова грамотність відображає знання про фінансові продукти, уміння їх використовувати, приймати при необхідності виваженні фінансово-економічні рішення чітко розуміючи свої дії в даній сфері (витрати або заощадження, вибір правильного сучасного фінансового продукту або інституту та інші).

Фінансова грамотність поєднує знання і навички, які повинні формуватися i розвиватися довгостроковою життєвою стратегією будь-якої людини, в контексті розуміння ключових фінансових понять, а саме: розуміння ризиків і дохідності, інфляції, простого та складного проценту, знання механізмів функціонування фінансового ринку та вміти знаходити інформацію про стан та динаміку його змін, розуміти причини і наслідки податкової відповідальність, вміти читати договори і розуміти їх зміст, вміти оцінювати пропозиції фінансових інституцій і визначати ступень їх перспективної стабільності.

Відповідно до визначення Управління 3 регулювання і нагляду у сфері фінансових послуг Великобританії, фінансова грамотність - це здатність людей жити на ті кошти, які є в їхньому розпорядженні, стежити за станом своїх фінансових ресурсів, планувати свої майбутні доходи і витрати (особливо пенсію), правильно обирати фінансові продукти і вміти розбиратися в життєвовиникаючих фінансових проблемах і питаннях [2; 7-9].

Велика Британія вважається однією з провідних країн у сфері фінансової грамотності. Цьому сприяє, зокрема, досить високий загальний рівень інформованості населення 3 питань фінансової грамотності, розвиток демократичних інституцій і фінансового ринку, усі учасники якого активно залучаються до фінансової освіти населення [4].

Цікавим є і досвід уряду Сполучених Штатів Америки (США), яким було створено Комісію 3 фінансової грамотності та освіти, а також Консультативну раду з фінансової грамотності при президенті. У доповіді Консультативної ради з фінансової грамотності США наводиться таке ії̈ визначення: «Уміння ефективно використовувати знання і навички з управління фінансовими ресурсами для досягнення фінансового благополуччя» [2].

Рівень фінансової грамотності населення різних країн значно відрізняється. Існують різні детермінанти в системі освіти фінансової грамотності, які визначаються національною, регіональною і соціальною специфікою країни, в якій впроваджуються сучасні програми підвищення фінансової освіти громадян. Такі програми діють у США, Великобританії, Бельгії, Фінляндії, Польщі, Румунії, Австрії, Німеччині, Канаді, Угорщині, Іспанії, Італії, Чехії, Норвегії, Австралії, Індонезії, Південній Африці та інших країнах.

На сьогодні, в міжнародній практиці існує розподіл країн по рівню розуміння впливу фінансової грамотності населення на їх економічний і соціальний розвиток, і саме, на державу покладається ключова роль координатора цього процесу:

- країни із високим ступенем розуміння значущості фінансової грамотності населення та масштабності фінансової освіти, це країни: Великобританія, Канада, Нова Зеландія, Франція, Німеччина, Сінгапур, а лідером впровадження фінансової освіти населення і вирішення проблем фінансової культури є США;

- країни із державним усвідомленням важливості фінансової освіти, але відсутністю належної підтримки, це Італія, Чехія, Голландія, Австрія, Польща, Україна, Індія, (згідно досліджень, Україна за останні роки з групи із початковим рівнем осмислення впливу фінансової грамотності на економічний та соціальний розвиток країни піднялась до другої групи, і це є дуже позитивною динамікою змін);

- країни із початковим рівнем осмислення впливу фінансової грамотності громадян на економічний та соціальний розвиток країни й початком процесу ініціалізації проектів і програм забезпечення фінансової грамотності населення (Росія, Китай).

Досвід розвинених країн свідчить про різні за своїм характером форми участі держави у процесі підвищення рівня фінансової грамотності населення, держава може:

- виступати координуючим центром реалізації інформаційно-освітніх програм та забезпечувати функціонування єдиних інформаційних баз і каналів поширення інформації;

- повністю або частково фінансувати реалізацію інформаційно-освітніх програм;

- формувати стандарти поширюваної виробниками фінансових послуг інформації та характерні процедури її розкриття;

- повністю самостійно реалізовувати всі детермінанти дій із розвитку фінансової грамотності (саме ця реалізація всіх заходів $\epsilon$ найбільш централізованою формою участі держави, проте майже не використовується на практиці, оскільки, як правило, країни залучають недержавні інститути для охоплення і реалізації програм фінансової грамотності населення). [2; 8-10].

Всі вище зазначені форми участі держави у підвищенні рівня фінансової грамотності, як правило, комбінуються і не використовуються в чистому вигляді. В ідеалі втручання держави повинно бути, лише тоді, коли воно є необхідною умовою здійснення заходу або ж призводить до значної економії витрат і підвищення ефективності реалізації проекту. Тому на різних стадіях реалізації освітньо- 
інформаційних програм (від розробки до поширення) характер і ступінь участі держави повинен варіюватися.

До реалізації програм розвитку фінансової грамотності населення і це усвідомлюється всіма розвиненими країнами, необхідно залучати широкий перелік відповідних організацій, які розподіляються наступним чином:

- державні організації, які, визначаючи напрями і пріоритети державної політики, також беруть участь у формуванні стратегії розвитку фінансової грамотності, реалізації програм і формуванні правового середовища відповідних ринків. Як правило, такими організаціями є соціальні структури, відповідальні за питання освіти, працевлаштування і пенсійне страхування; організації які регулюють ринки сучасних фінансових послуг і забезпечують захист прав споживачів;

- некомерційні (державні) громадські організації (які фінансуються або за рахунок держави або за рахунок приватного сектору), які активно залучаються до процесу реалізації стратегії підвищення рівня фінансової грамотності населення на всіх стадіях (починаючи 3 досліджень і розробки програми стратегіi);

- приватні галузеві організації або різного роду асоціації, що представляють інтереси галузі, реалізують значну частку програм у сфері фінансової грамотності населення.

Форми участі приватного сектору аналогічні державним формам за винятком формування загальних стандартів інформаційних програм і процедур розкриття інформації [2].

Як було вище зазначено, США $є$ однією із провідних країн, яка приділяє значну увагу формуванню фінансової грамотності населення. Там, як і в усьому світі, $\epsilon$ доволі гострою проблема заборгованості населення, що, в свою чергу, змушує органи влади запроваджувати заходи щодо вирішення питань, пов'язаних із підвищенням рівня фінансової грамотності населення. Американську модель фінансової освіти побудовано як багаторівневу систему підготовки споживачів фінансових послуг з чітко диференційованою структурою постачальників послуг, в якій кожен рівень відповідає життєвому циклу людини. Діюча система фінансової освіти об’єднує потенційних і реальних споживачів фінансових послуг. Центральним елементом цієї моделі $є$ державне управління, яке відповідає як за фінансову незалежність держави, так і за координацію фінансового захисту та фінансових знань громадян у всій країні.

У Сполучених Штатах просування освітніх програм фінансової грамотності здійснюється досить активно. Формування поведінкових навичок, культури ділового спілкування, здатність відстоювати свої права при цьому не порушуючи права інших членів суспільства, вміння вести переговори, працювати в команді, ризикувати і правильно оцінювати шанси на успіх, освоєння навичок користування кредитними картками, вміння оцінювати і обирати схеми медичного страхування, розраховувати податкові платежі, аналізувати необхідність і доцільність взяття кредиту тощо, всі ці питання є обов'язковими і важливими для студентства [4].

Водночас у структурі бюджету уряду США не передбачено жодного цента, завданням якого було б підвищення рівня фінансової грамотності населення. Практично всі заходи здійснюються за ініціативою та безпосередньою участю волонтерів і некомерційних організацій, а спеціальні фонди для цих цілей формуються за рахунок добровільних пожертв юридичних і приватних осіб. Незважаючи на це, фінансова грамотність у США набула статусу національного руху. Окреслена модель розвитку дає змогу фінансовій грамотності бути достатньо гнучкою, варіативною і певною мірою вільною, тим самим даючи змогу накопичувати унікальний досвід роботи 3 різними цільовими групами людей, що проживають у різних географічних і соціальних умовах [3].

Окрім того, серед країн, які мають та реалізують на практиці національні стратегії фінансової грамотності є Канада, Ірландія, Австралія, Угорщина, Бразилія, Малайзія, Нова Зеландія, Чехія, Сінгапур, Польща, Південна Африка, Великобританія, Росія, Білорусь, Азербайджан, Грузія, країни Балтії, Казахстан та інші [3].

У світовій практиці неабияким попитом користується професія радника у сфері особистих фінансів, особливо у США, де вона вже існує майже 20 років. У Європі приблизно 50\% усіх угод здійснюється через фінансових консультантів, у США цей показник перевищує 60\%, а в Австралії - 80\%; щодо України, то це лише 3\% всіх угод. Консультант не продає фінансові продукти, а допомагає клієнтам зберегти та примножити свої кошти, у цьому разі він повністю приймає позицію клієнта. Такий високий попит на фінансових консультантів також спричинений великою кількістю інвесторів [5; 7; 8].

У міжнародній практиці використовуються різні способи навчання молоді рахувати власний бюджет, бути фінансово обізнаними, володіти базовими знанням про фінансові інструменти та послуги. Так, наприклад, у Польщі організація Фундація Кроненберг у кооперації із Citi Bank уже більше двадцяти років розробляє і втілює програми для фінансової освіти населення, зокрема програма «Мої Фінанси» є найбільшою молодіжною програмою економічної освіти в Польщі, метою якої є навчання молодих людей приймати раціональні та вигідні фінансові рішення і регулярно оновлювати свої фінансові знання. «Підприємницька програма» фінансової освіти адресована студентам старших класів 
середньої школи. Здійснюється у співпраці з Фондом Досягнень Молоді. Мета проекту полягає в передачі знань про підприємництво студентам та допомозі їм розвинути навички та компетенції в цій галузі. Проект Business Startup є національною програмою, що призначена для студентів та випускників. Учасники проекту проходять навчання і консультування, що розроблені для допомоги їм у перетворені їх бізнес-ідей в реальний бізнес [4]. Метою програми є стимулювання підприємництва серед студентів і допомога їм у відкритті своїх власних фірм.

Дослідження, проведені в Польщі, показують, що молодь сприймає навчання у цій сфері i зацікавлена в ньому; дорослих навчити важче, адже вони в переважній своїй кількості не проявляють ініціативу щодо вивчення додаткової інформації з приводу фінансів, що породжує вагомі труднощі під час вирішення конкретних питань із приводу використання коштів.

У Великобританії та США фінансова грамотність регулюється законами, в інших державах, таких як Бельгія, Австралія, Франція, Австрія, Польща, активно користуються проектами, здебільшого це Інтернет-ресурси та платформи, які переважно розроблені у формі інтерактивних ігор. Удалими програмами підвищення фінансової грамотності є: «Відповідальність за майбутнє» (США), «Фінанси і педагогіка» (Франція), «Фінансові водійські права» (Австрія), «Економія пенсії» (Швеція), «Вмій планувати своє майбутнє» (Польща), «Фінансова грамотність на роботі: змусь гроші працювати» (Великобританія), «Гроші говорять!» (Угорщина), «Фінансова грамотність. Розуміння грошей» (Австралія) та ін. Програми, як правило, створюються з урахуванням культурної специфіки тієї чи іншої країни або адаптуються під цю специфіку [5].

Представники Агентства США 3 міжнародного розвитку USAID «Міжнародні партнерства заради стабільності фінансового сектору» провели опитування серед населення, щоб з'ясувати, наскільки громадяни України розуміються на фінансовій системі і взаємодіють із нею. Дослідження проводилось у серпні 2021 р. В опитуванні взяли участь 2040 українців віком від 18 до 79 років. За даними дослідження USAID «Фінансова грамотність, обізнаність та інклюзія в Україні» у 2021 році Україна зросла за рівнем фінансової грамотності як у порівнянні з 2018 р., так і в порівнянні з іншими країнами (тренди України іноді суттєво кращі, ніж інших країн); залишаються розбіжності у фінансовій грамотності за віком, місцем проживання, освітою і доходами, що є характерним і для країн дослідження ОЕСР за 2020 р. Водночас, практично відсутні відмінності за статтю (у Звіті ОЕСР навпаки питання відмінностей між фінансовою грамотністю чоловіків і жінок є релевантним); українці мають нижчий рівень доходу та відповідно менший запас міцності на випадок втрати основного джерела доходу та відчувають більший стрес через стан своїх фінансів порівняно із опитаними з країн порівняння. За методологією ОЕСР, загальний індекс фінансової грамотності України становить 12,3 бали (або 58\% від його максимального значення). Індекс фінансової грамотності в Україні наразі демонструє гарну динаміку - за менше ніж 3 роки відбулося зростання на 6,0\% у бальному вираженні; усі компоненти індексу покращилися [6].

Нове дослідження фінансової грамотності в Україні, проведене 3 використанням методики Організації економічного співробітництва і розвитку (ОЕСР), показало, що Україна разом з Польщею знаходиться на 30-ому та останньому місці у рейтингах.

Результат України за Індексом фінансової грамотності ОЕСР (знання, ставлення, поведінка) становить 11,6 балів (проти 13,2, що є середнім показником тридцяти країн) і переконливо свідчить про те, що Національна стратегія з підвищення фінансової грамотності є вкрай важливою. Рівень фінансової грамотності є найнижчим у віковій групі 18-24 роки (10,6 балів проти 12,1 у віковій групі 25-34 роки). Це вказує на те, що пріоритетними могли б стати ініціативи 3 фінансової грамотності для підлітків і молоді. Українці рішуче підтримують викладання фінансової грамотності у школах - 70\% хотіли б, щоб дітей навчали в школі, як розпоряджатися своїми фінансами.

Дослідження демонструє, що програми 3 фінансової грамотності повинні бути одним 3 найважливіших пріоритетів для України. Люди з нижчими доходами, нижчим рівнем освіти та ті, які не мають банківських рахунків, демонстрували нижчі результати та почувалися менше фінансово забезпеченими. Такі українці найбільше б виграли від фінансової просвіти [6]. Найбільш проблемними $є$ питання, які стосуються кредитування: обчислення реальної ставки відсотка, відповідальність банків розкривати цю реальну ставку позичальникам, поняття плаваючої ставки та відповідальність поручителя за споживчим кредитом [4]. Очевидно, що українці цікавляться лише тими фінансовими темами, які мають для них персональну важливість.

Щоб наблизитися до вирішення даної проблеми, потрібно не тільки сформувати понятійний апарат, а й, використовуючи досвід інших країн, розробити систему підвищення рівня фінансової грамотності. У таких країнах, як США, Австрія, Великобританія, підвищення фінансової грамотності населення включено в один із пріоритетних напрямів державної політики, тому там проводяться систематичні дослідження, спрямовані не тільки на визначення рівня фінансової грамотності, а й на виділення пріоритетних напрямів фінансової освіти громадян. Незважаючи на те що соціальноекономічний результат від підвищення фінансової грамотності проявляється поступово, світова практика 
підтверджує безперечну необхідність проведення такої роботи і неприпустимість зволікання у вирішенні цієї проблеми [2; 6-8].

Враховуючи передовий зарубіжний досвід та беручи його за основу в життєвих реаліях нашої країни, вважаємо, що для підвищення рівня фінансової грамотності населення, перш за все, необхідно вжити наступних заходів:

- робота з вразливими групами населення за віком і за місцем проживання. Найбільші проблеми 3 фінансовою грамотністю спостерігаються у таких вікових групах, як 18-24 роки (а особливо 18-19 років) та старше 60 років. Також сільське населення має прогалини у фінансовій грамотності. Таким чином, необхідно переформатувати заходи з фінансового просвітництва найбільш прийнятним чином для цих груп населення, в тому числі через формування адекватних каналів поширення інформації. Необхідно зауважити, що онлайн-освіта не завжди є доступною для зазначених груп населення, а це актуалізує питання проведення офлайн-заходів. Відзначимо, що прогрес останніх років в Україні значною мірою був забезпечений просвітницькими заходами за підтримки міжнародних донорів, i реалізацію цих заходів варто продовжувати, щоб зберегти і примножити отриманий ефект;

- проведення роз'яснювальної роботи щодо переваг користування фінансовими продуктами серед населення України. Звісно, це необхідно робити не тільки на рівні фінансових регуляторів, а швидше на рівні фінансових інститутів, які й є кінцевими продуцентами фінансових послуг. Важливо відзначити, що усвідомлення фінансовими установами своєї відповідальності за недоброчесну поведінку щодо споживачів 7 фінансових послуг, зокрема, в частині розкриття інформації про фінансову послугу, стане міцним підгрунтям для зростання довіри до фінансових установ;

- спрямування зусиль фінансових регуляторів на посилення захисту прав споживачів фінансових послуг та інформування споживачів про вже наявні можливості їх відстоювання. Дослідження показало, що $10 \%$ у 2021 р. (12\% у 2018 р.) респондентів не знають про наявність гарантування вкладів фізичних осіб і тільки $31 \%$ у 2021 р. (27\% у. 2018 р.) респондентів знають, що банки мають розкривати інформацію про реальну відсоткову ставку за кредитом.

Тому сьогодні, як ніколи, необхідно створити інститут незалежних фінансових консультантів, які будуть працювати не на банк або страхову компанію, а працювати на свого клієнта, захищати його інтереси. Звичайно, необхідно створити на державному рівні умови отримання відповідної освіти, яка б відповідала нормам та вимогам міжнародних стандартів, і для якої були б створені державні стандарти і методологія [1].

Відомо, що на нинішньому фінансовому ринку працює багато фінансових посередників. Наприклад, це страховий агент - який є представником компанії, він діє від імені і за дорученням страхової компанії. Або брокер - також учасник ринку, але який діє вже від свого імені і за дорученням клієнта. Клієнтом брокера можуть бути як страхові компанії, так і люди, що бажають укласти договір страхування. I цих два суб’єкти ринку страхових послуг працюють доти, поки не виникає ситуація, наприклад, коли людина бере іпотечний кредит, умовою якого є страхування заставного майна. Виникає більш широке поле фінансових інструментів. Саме тут і потрібні фінансові консультанти, які можуть допомогти людині під час укладення кредитного та страхового договорів, відповідно до інших угод, укладених між позичальником і кредитором. Тобто фінансовий консультант - це одночасно кредитний, іпотечний, інвестиційний та страховий посередник, він поєднує в собі всі напрямки. І що дуже важливо, він захищає інтереси клієнта [1; 7-10].

\section{Висновки}

Фінансова грамотність є одним із найважливіших чинників росту економіки: чим більше населення буде задіяне на фінансовому ринку та чим вище буде попит на фінансові послуги, тим більше буде виникати передумов для підвищення рівня ефективності фінансової системи і сталого розвитку держави у цілому. Для збільшення рівня залучення різних верств населення до користування фінансовими послугами необхідне впровадження комплексних заходів щодо забезпечення фінансової обізнаності з урахуванням особливостей кожної цільової групи. Виходячи 3 того, що проблема фінансової грамотності стосується державної економіки, то й вирішуватися вона повинна насамперед на державному рівні починаючи $з$ визначення основної ланки серед державних органів, що буде виступати координатором здійснення запланованих національних ініціатив.

Підсумовуючи, ми констатуємо, що завдання підвищення фінансової грамотності, безумовно, є обов'язком держави, бізнесу та сім’і. Проте, щоб досягти належного рівня фінансової грамотності, ми маємо насамперед подолати відверто пасивне ставлення більшості українців до створення власного добробуту та розвинути філософію самозайнятості наших співвітчизників, яка дає змогу кожному громадянину отримати фінансову допомогу. незалежність і зберігати ії все своє життя. Кожен українець повинен розуміти, що сьогодні бути фінансово грамотною людиною надзвичайно необхідно. Зрештою, фінансова грамотність означає, що ви можете керувати своїми грошима, щоб отримати фінансову незалежність за допомогою інструментів та навичок управління грошима, доступних на сучасному ринку. 
Аналіз ситуації в Україні показує, що детермінанти підвищення рівня фінансової грамотності реалізуються, переважно, в рамках шкільної освіти у вигляді факультативів. Професійно-технічні заклади практично не приділяють уваги фінансовій освіті своїх студентів. Та лише деякі виші, проявляють інтерес до програм з підвищення фінансової грамотності. Тому пропонуємо в якості стратегії розвитку фінансової освіти передбачити вивчення фінансових аспектів в рамках базових дисциплін/предметів неекономічних спеціальностей. Важливе значення в поширені необхідних фінансових знань враховуючи світовий досвід, має діяльність громадських освітніх організацій, розробка та впровадження безкоштовних on-line курсів за цільовою аудиторією та відповідно особливостей різних категорій громадян.

\section{Список використаної літератури}

1. Радзішевська Д. В. Підвищення фінансової грамотності населення України як один із пріоритетів державної політики на сучасному етапі. http://academy.gov.ua/ej/ej13/txts/Radzishevska.pdf ( дата звернення 01.12.2021).

2. Дудчик О. Ю., Матвійчук I. О. Фінансова грамотність населення: теоретичні аспекти, проблеми і перспективи поліпшення в Україні. Інфраструктура ринку. 2019. Вип. 31. С. 631-635.

3. Слобода Л. Я. Фінансова грамотність як чинник забезпечення ефективності використання банківського капіталу. Вісник Університету банківськоӥ справи Національного банку України. 2011. № 2 (11). C. 167-172.

4. Гончар Л. В., Гарна С. О., Мартиненко А. О. Фінансова грамотність населення України як фактор успішного розвитку держави. Інноваційна економіка. 2019. Вип.1-2. С. 182-186.

5. Гаврилко Т. О., Довгань М. М. Фінансова грамотність населення: вітчизняний та зарубіжний досвід. Приморські економічні студіï. 2018. Вип. 30-2. С. 48-52.

6. Фінансова грамотність, фінансова інклюзія та фінансовий добробут в Україні у 2021: звіт за результатами дослідження для DAI Global LLC, Проекту USAID «Трансформація фінансового сектору». 2021. 80 c. URL : http://www.fst-ua.info/wp-content/uploads/2021/10/Ukraine_2021_Financial-LiteracySurvey-Report UA.pdf (дата звернення 25.11.2021).

7. Tanklevska, N., Povod, T., Ostapenko, A., Borovik, L. Crowdfunding Development Trends: Foreign Experience and Ukrainian Realities in the Digital Economy. Conference Paper. Lecture Notes in Networks and Systems, 2021, 194 LNNS, p. 897-908 https://link.springer.com/chapter/10.1007\%2F978-3-030-69221-6_69 (дата звернення 25.11.2021).

8. Танклевська Н. С., Повод Т. М. Поведінкова економіка: етимологія, сутність, теорія. Науковий вісник Льотної академії. Серія: Економіка, менеджмент та право. 2021. Вип. 3,4. С. 38-45. URL: http://hdl.handle.net/123456789/6213 (дата звернення 01.12.2021).

9. Танклевська Н. С., Ярмоленко В. В. Тенденції розвитку страхування сільськогосподарських культур в Україні. Науковий вісник Ужгородського університету. Серія «Економіка». 2018. Вип. 1(51). С. 381-386. URL: http://dspace.ksau.kherson.ua/handle/123456789/1632 12 (дата звернення 22.11.2021).

10. Ярмоленко В. В. Вплив факторів на функціонування ринку агрострахування. БІЗНЕСІНФОРМ. Економіка. Економіка сільського господарства і АПК. 2019. № 9. С. 144-151. URL: http://dspace.ksau.kherson.ua/handle/123456789/1640 (дата звернення 30.11.2021).

\section{References}

1. Radzishevs'ka D. V. (2021) Pidvyshchennya finansovoyi hramotnosti naselennya Ukrayiny yak odyn iz priorytetiv derzhavnoyi polityky na suchasnomu etapi. URL: http://academy.gov.ua/ej/ej13/txts/Radzishevska.pdf (access date 01.12.2021).

2. Dudchyk O. YU., Matviychuk I. O. (2019) Finansova hramotnist' naselennya: teoretychni aspekty, problemy i perspektyvy polipshennya v Ukrayini. Hroshi, finansy i kredyt, Vyp. 31. p. 631-635.

3. Slovoda L. (2011) Finansova ghramotnistj jak chynnyk zabezpechennja efektyvnosti vykorystannja bankivsjkogho kapitalu [Financial literacy as a factor in ensuring the effciency of using bank capital]. Bulletin of the University of Banking of the National Bank of Ukraine, No. 2 (11), pp. 167-172.

4. Honchar L. V., Harna S. O., Martynenko A. O. (2019) Finansova hramotnist' naselennya Ukrayiny yak faktor uspishnoho rozvytku derzhavy. Innovatsiyna ekonomika, Vyp.1-2, P. 182-186.

5. Havrylko T. O., Dovhan' M. M. (2018) Finansova hramotnist' naselennya: vitchyznyanyy ta zarubizhnyy dosvid. Prymors'ki ekonomichni studiyi. Vyp. 30-2. P. 48-52.

6. Finansova hramotnist', finansova inklyuziya ta finansovyy dobrobut v Ukrayini u 2021: zvit za rezul'tatamy doslidzhennya dlya DAI Global LLC, Proektu USAID «Transformatsiya finansovoho sektoru». 2021. 80 p. URL : http://www.fst-ua.info/wp-content/uploads/2021/10/Ukraine_2021_Financial-LiteracySurvey-Report_UA.pdf (access date 25.11.2021).

7. Tanklevska, N., Povod, T., Ostapenko, A., Borovik, L. Crowdfunding Development Trends: Foreign Experience and Ukrainian Realities in the Digital Economy. Conference Paper. Lecture Notes in Networks and Systems, 2021, 194 LNNS, p. 897-908 https://link.springer.com/chapter/10.1007\%2F978-3-030-69221-6 69 (access date 25.11.2021). 
8. Tanklevs'ka N. S., Povod T. M. (2021) Povedinkova ekonomika: etymolohiya, sutnist', teoriya. Naukovyy visnyk L'otnoyi akademiyi. Seriya: Ekonomika, menedzhment ta pravo, 2021. Vyp. 3,4. S. 38-45. URL: http://hdl.handle.net/123456789/6213 (access date 01.112.2021).

9. Tanklevs'ka N. S., Yarmolenko V. V. (2018) Tendentsiyi rozvytku strakhuvannya sil's'kohospodars'kykh kul'tur v Ukrayini. Naukovyy visnyk Uzhhorods'koho universytetu. Seriya «Ekonomika». Vyp.1(51). S. 381-386. URL: http://dspace.ksau.kherson.ua/handle/123456789/1632 12 (access date 22.11.2021).

12. Yarmolenko V.V. (2019) Vplyv faktoriv na funktsionuvannya rynku ahrostrakhuvannya. BIZNESINFORM. Ekonomika. Ekonomika sil's'koho hospodarstva i APK. № 9. p. 144-151 URL: http://dspace.ksau.kherson.ua/handle/123456789/1640 (access date 30.11.2021). 